\title{
Screening Differential Expressions of Defense-related Responses in Cold-treated 'Kyoho' and 'Campbell Early' Grapevines
}

\author{
Soon Young Ahn ${ }^{1}$, Seon Ae Kim ${ }^{1}$, Jae Hyun Han ${ }^{1}$, Seung Heui Kim², and Hae Keun Yun ${ }^{1 *}$ \\ ${ }^{1}$ Department of Horticulture and Life Science, Yeungnam University, Gyeongsan 712-749, Korea \\ ${ }^{2}$ National Institute of Horticultural \& Herbal Science, Rural Development Administration, Suwon 441-706, Korea
}

\begin{abstract}
Low temperature is one of the major environmental factors that affect productivity including reduced growth and budding of vines, and changes of metabolic processes in grape (Vitis spp.). To screen the specific expression of abiotic stress-related genes against cold treatment in 'Kyoho' and 'Campbell Early' grapevines, expression of various defense-related genes was investigated by RT-PCR and real-time PCR. Among the 67 genes analyzed by RT-PCR and real-time PCR, 17 and 16 types of cDNA were up-regulated, while 5 and 6 types were down-regulated in cold-treated 'Kyoho' and 'Campbell Early' grapevines, respectively. Genes encoding carotene (Cart3564 and Cart4472), chalcone isomerase (CHI), cytochrome P450 (CYP), flavonol synthase $(F L S)$, endo- $\beta$-glucanase precursor $(G l u)$, glutathione peroxidase $(G P X)$, glutathione- $S$-transferase (GST), leucine-rich repeats $(L R R)$, manganese superoxide dismutase $(M n-S O D)$, phenylalanine ammonia lyase $(P A L)$, polygalacturonase-inhibiting protein $(P G I P)$, proline rich protein $2(P R P 2)$, small heat shock protein $(s H S P)$, temperature induced lipocalin $(T I L)$, and thaumatin-like protein $(T L P)$ were up-regulated, while those encoding CBF like transcription factor $(C B F 1)$, chitinase-like protein $(C L P)$, cold induced protein $(C I P)$, glycerol-3-phosphate acyltransferase (GPAT), and mitogen-activated protein kinase (MAPK) were down-regulated by low temperature treatment in both in 'Kyoho' and 'Campbell Early'.
\end{abstract}

Additional key words: abiotic stress, low temperature, real-time PCR, Vitis

\section{Introduction}

Grapes (Vitis spp.) are the most widely cultivated and economically important fruit crop worldwide (Vivier and Pretorius, 2002). Vitis vinifera cultivars grow well in temperate, semi-arid climates that can sometimes experience freezing or subfreezing temperatures during winter (Tillett et al., 2012). One of the most variable environmental factors to which plants are exposed is temperature. Changes in temperature affect many metabolic processes in plant cells, and may also modify structural components in plants (Hughes and Dunn, 1990).

Low temperature is one of the major environmental factors affecting the growth and development of plants and significantly constraining the spatial distribution of plants and agricultural productivity. When a plant is exposed to suboptimal low temperatures, many cellular functions are disturbed (Feng et al., 2009), leading to various changes in the hormone levels (Chandler and Robertson, 1994), membrane lipid composition (Lynch and Steponkus, 1987), and antioxidants levels (Pennycooke et al., 2005). The accumulation of compatible osmolytes, such as soluble sugars, betaine, and proline, also occurs in cold-stressed plants (Dorffling et al., 1997; Koster and Lynch, 1992; Nomura et al., 1995).

Screening expression of specific genes that respond to cold can provide helpful resources in breeding programs of cold-tolerant grapes, and can aid in our understanding of molecular mechanisms of responses to cold in plants. Therefore, in this study, we screened differentially expressed genes in grapevines following cold treatment to provide useful information and increase the efficiency at developing new grape cultivars with improved cold tolerance through molecular breeding programs.

\footnotetext{
*Corresponding author: haekeun@ynu.ac.kr

※ Received 10 January 2013; Revised 13 February 2013; Accepted 15 February 2013. This work was supported by a grant (PJ008224) from the Agricultural R\&D Project, Rural Development Administration, Republic of Korea, and by the 2012 Post-Doctoral Course Program of Yeungnam University, Republic of Korea.
} 


\section{Materials and Methods}

\section{Plant Materials and Cold Treatment}

Grapevines of 'Kyoho' (sensitive to cold stress) and 'Campbell Early' (moderately tolerant to cold stress) (Kang et al., 2002) with 8-10 true leaves were grown in a greenhouse maintained at $4^{\circ} \mathrm{C}$ under 16:8 light:dark illumination for $0,1,2,3$, and 4 weeks, respectively. Leaves were harvested from the vines at $1,2,3$, and 4 weeks, immediately frozen in liquid nitrogen, and then stored at $-80^{\circ} \mathrm{C}$ for future use. Leaves harvested from untreated vines were used as an untreated control.

RNA Isolation and Semi-quantitative RT-PCR and Realtime PCR Analysis

Total RNA was extracted from grapevine leaves using a modified version of the method described by Chang et al. (1993). The differential expression of genes was screened by semi-quantitative RT-PCR using gene specific primer pairs. First-strand cDNA was synthesized from the total RNA (500 ng) using a PrimeScript ${ }^{\mathrm{TM}} 1^{\text {st }}$ strand cDNA synthesis kit (Takara Bio Inc., Japan) and subsequently used as a template for PCR. The actin gene primers were used as an internal control. PCR was conducted by subjecting the samples to the following conditions: initial denaturation for $5 \mathrm{~min}$ at $94^{\circ} \mathrm{C}$ followed by 30 cycles of $94^{\circ} \mathrm{C}$ for $45 \mathrm{~s}, 55^{\circ} \mathrm{C}$ for
$45 \mathrm{~s}$, and $72^{\circ} \mathrm{C}$ for $1 \mathrm{~min}$ and then final extension for 7 min at $72^{\circ} \mathrm{C}$. The PCR products were subsequently identified by $1 \%(\mathrm{~W} / \mathrm{V})$ agarose gel electrophoresis with $0.5 \mathrm{X} \mathrm{TBE}$ running buffer. Quantitative real-time PCR was conducted on a $\mathrm{C} 1000^{\mathrm{TM}}$ Thermal Cycler (BioRad, USA) using SYBR Premix Ex (TaKaRa Bio Inc., Japan) as the fluorescent dye. All reactions were performed in triplicate to ensure consistency of the results. Amplification was carried out as follows: $95^{\circ} \mathrm{C}$ for $30 \mathrm{~s}$, followed by 40 cycles of $95^{\circ} \mathrm{C}$ for $5 \mathrm{~s}, 60^{\circ} \mathrm{C}$ for $30 \mathrm{~s}$. Transcript levels were calculated using the standardcurve method and normalized using grapevine actin gene (AB372563.1) as internal control and melting curves of the amplified products were recorded.

\section{Results and Discussion}

Overall, the expression of 67 genes related to defense to biotic or abiotic stress in plants were evaluated following cold treatment of 'Kyoho' and 'Campbell Early' grapevines using semi-quantitative reverse transcription PCR (RT-PCR).

Among the genes screened, those encoding carotene (Cart3564 and Cart4472), chalcone isomerase (CHI), cytochrome $\mathrm{P} 450$ $(C Y P)$, flavonol synthase (FLS), endo- $\beta$-glucanase precursor $(G l u)$, glutathione peroxidase $(G P X)$, glutathione- $S$-transferase $(G S T)$, leucine-rich repeats $(L R R)$, manganese superoxide
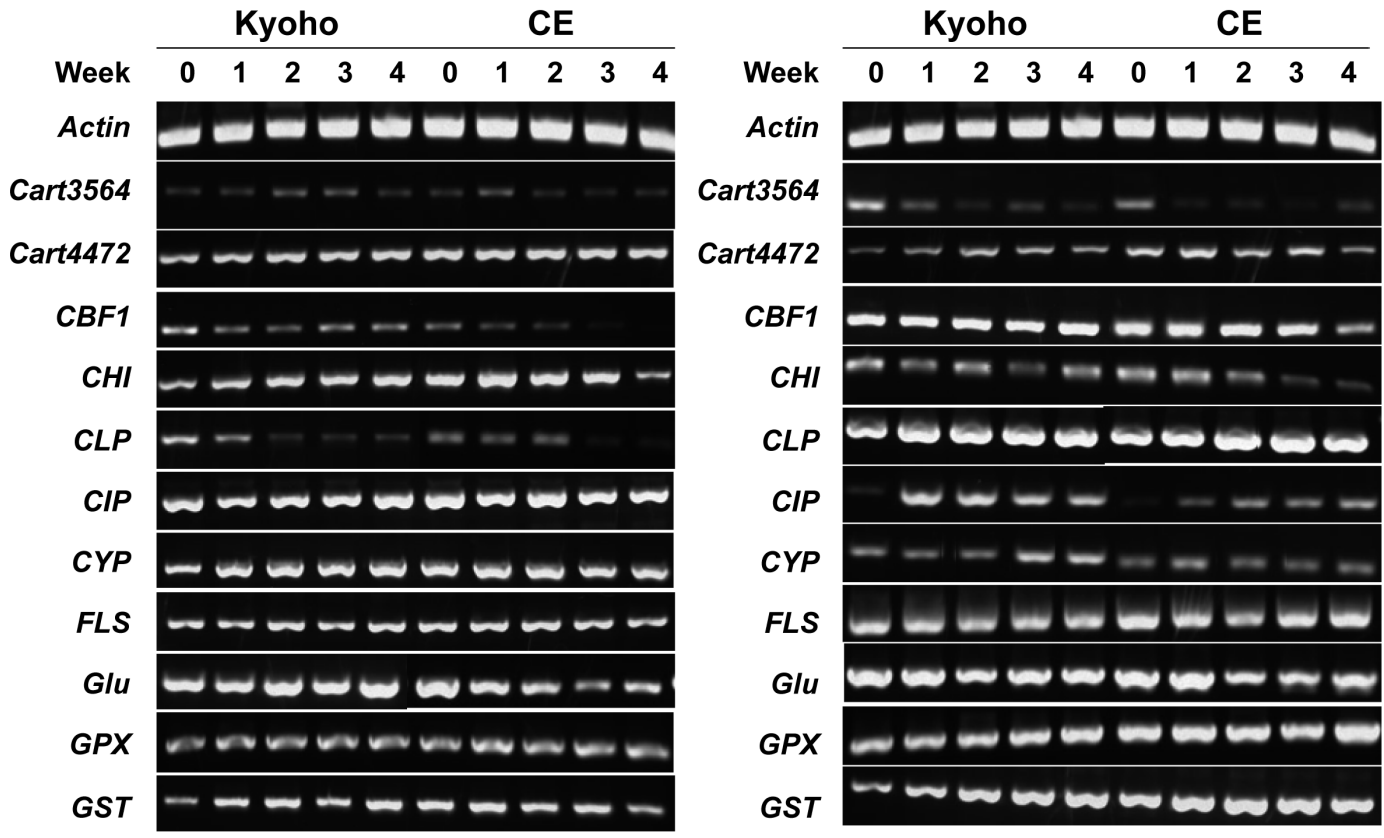

Fig. 1. Semi-quantitative RT-PCR analysis to screen genes induced in shoots of 'Kyoho' and 'Campbell Early' grapevines in response to cold. Cart3564 and Cart4472, carotene; CBF1, CBF like transcription factor; CHI, chalcone isomerase; CLP, chitinase-like protein; CIP, cold induced protein; CYP, cytochrome P450; FLS, flavonol synthase; Glu, endo- $\beta$-glucanase precursor; GPX, glutathione peroxidase; GST, glutathione-S-transferase; GPAT, glycerol-3-phosphate acyltransferase; $L R R$, leucine-rich repeats; $M n-S O D$, manganese superoxide dismutase; MAPK, mitogen-activated protein kinase; $P A L$, phenylalanine ammonia lyase; $P G I P$, polygalacturonase-inhibiting protein; $P R P 2$, proline rich protein 2; $P 5 C S$, pyrroline-5-carboxylate synthase; sHSP, small heat shock protein; TIL, temperature induced lipocalin; TLP, thaumatine-like protein. 
dismutase $(M n-S O D)$, phenylalanine ammonia lyase $(P A L)$, polygalacturonase-inhibiting protein $(P G I P)$, proline rich protein 2 (PRP2), small heat shock protein ( $S H S P)$, temperature induced lipocalin $(T I L)$, and thaumatin-like protein (TLP) were up-regulated, while genes encoding CBF like transcription factor $(C B F 1)$, chitinase-like protein $(C L P)$, cold induced protein $(C I P)$, glycerol-3-phosphate acyltransferase (GPAT), and mitogen-activated protein kinase $(M A P K)$ were downregulated by low temperature treatment in both 'Kyoho' and 'Campbell Early' (Fig. 1 and Table 1).

Table 1. Sequences of gene specific primers used for RT-PCR analysis in this study.

\begin{tabular}{|c|c|}
\hline Name (accession no.) & Primer sequences \\
\hline Carotene 3564 (XM002265752.2) & $\begin{array}{l}\text { 5'-TGCTACTGAAGTTATGATTGGAAA-3' } \\
\text { 5'-CTCTAAACATGCAACTAATCAGC-3' }\end{array}$ \\
\hline Carotene 4472 (XM002274326.2) & $\begin{array}{l}\text { 5'-TATTGACCGCAACTTTCGTATTTA-3' } \\
\text { 5'-TCATGAAGTTGAAAGTACCAGAGA-3' }\end{array}$ \\
\hline CBF like transcription factor (CBF1) (AY390372.1) & $\begin{array}{l}\text { 5'-CTTAAGAAATCCAGGATATGGCTA-3' } \\
\text { 5'-TTAAACCTTGCATATTGAACATTG-3' }\end{array}$ \\
\hline Chalcone isomerase $(\mathrm{CHI})(\mathrm{XM002282072.2)}$ & $\begin{array}{l}\text { 5'-TCCCATCTCTCCTTCAACCA-3' } \\
\text { 5'-TATCCCCGAAGATGTCTCCA-3' }\end{array}$ \\
\hline Chitinase-like protein (CLP) (XM002269123.1) & $\begin{array}{l}\text { 5'-GAAGCCATTGGTGAAGGTGT-3' } \\
\text { 5'- GGGTGGCGTTCTGTTCTATG-3' }\end{array}$ \\
\hline Cold induced protein (CIP) (XM002283501.1) & $\begin{array}{l}\text { 5'-CCAAGTGTTTGGGAGTCCAT-3' } \\
\text { 5'-GCAGAACCCCTCTTCTTTGA-3' }\end{array}$ \\
\hline Cytochrome p450 (CYP) (CAB85635.1) & $\begin{array}{l}\text { 5'-AAGCAACGGTTACAGCTAAG-3' } \\
\text { 5'-GCCATATCTGTCTTCCATGT-3' }\end{array}$ \\
\hline Endo- $\beta$-glucanase precursor (Glu) (AB601116.1) & $\begin{array}{l}\text { 5'-TTGGTAACCCTGAAAGCTGA -3' } \\
\text { 5'-ACACCATATCCATGGTAGCC-3' }\end{array}$ \\
\hline Flavonol synthase (FLS) (XM002285805.1) & $\begin{array}{l}\text { 5'-AGCGGTACTCAGCAAAGGTT-3' } \\
\text { 5'-TGAGAAGGTTGAGTGGGTTG-3' }\end{array}$ \\
\hline Glutathione peroxidase (GPX) (XM003631370.1) & $\begin{array}{l}\text { 5'-CAGGGGTTTCCAGTTATTCG-3' } \\
\text { 5'-CACCCTCATCATGGTGCTTA-3' }\end{array}$ \\
\hline Glutathion-S-transferase (GST) (AY156048) & $\begin{array}{l}\text { 5'-GGCGATCAAAGTCCATGGTAG-3' } \\
\text { 5'-GCTTCTCCAATCCCTTAACCC-3' }\end{array}$ \\
\hline Glycerol-3-phosphate acyltransferase (GPAT) (XM002276065.1) & $\begin{array}{l}\text { 5'-TCTTCСTCTTCATTGTCTTCTTCT-3' } \\
\text { 5'-ACATGTAATAGTCAAAGGGCTCTC-3' }\end{array}$ \\
\hline Leucine-rich repeats $(L R R)$ (XM002285517.2) & $\begin{array}{l}\text { 5'-TCGTGGAGTGGCTATGACTG-3' } \\
\text { 5'-GTGTTGAGAGAACCGCCATT-3' }\end{array}$ \\
\hline Manganese superoxide dismutase (Mn-SOD) (EU280161.1) & $\begin{array}{l}\text { 5'-ATAACCCCCTACAACAAAGCCCTA-3' } \\
\text { 5'-CTTTCCATACGTTCTTCAGGTAAT-3' }\end{array}$ \\
\hline Mitogen-activated protein kinase (MAPK) (AY395740.1) & $\begin{array}{l}\text { 5'-CATAGACACGATTAAAGTGATTGG-3' } \\
\text { 5'-GATCTTCACTTCTCCTCTGTGATT-3' }\end{array}$ \\
\hline Phenylalanine ammonia lyase (PAL) (X75967.1) & $\begin{array}{l}\text { 5'-CCAGTTCTCAGAGCTTGTTAATGA-3' } \\
\text { 5'-ATACATGTTCCCTATCCACCACTT-3' }\end{array}$ \\
\hline Polygalacturonase-inhibiting protein (PGIP) (AF305093.1) & $\begin{array}{l}\text { 5'-СTСTCСTССТСТСТССТССT-3' } \\
\text { 5'-CGGTGAGGTTAGAGAGCTTG-3' }\end{array}$ \\
\hline Proline rich protein2 (PRP2) (XR078193.2) & $\begin{array}{l}\text { 5'-TTGGTAACCCTGAAAGCTGA-3' } \\
\text { 5'-ACACCATATCCATGGTAGCC-3' }\end{array}$ \\
\hline Pyrroline-5-carboxylate synthase (P5CS) (AJ005686.1) & $\begin{array}{l}\text { 5'-ACTTCAAGAGAGGAGATCCCTAAT-3' } \\
\text { 5'-GAATATGATCAATGGCAGAATGTA-3' }\end{array}$ \\
\hline Temperature induced lipocalin (TIL) (DQ222993.1) & $\begin{array}{l}\text { 5'-AGATAGCTTCATTTCCCTCATTTT-3' } \\
\text { 5'-AAATAGATTTAATCCACCAAATGC-3' }\end{array}$ \\
\hline Thaumatin-like protein (TLP) (XM002282928.2) & $\begin{array}{l}\text { 5'- GTCAACCAATGCACCTAC-3' } \\
\text { 5'- GGTGGATCATCCTGTGGA-3' }\end{array}$ \\
\hline Small heat shock protein $(s H S P)(\mathrm{XM003634002.1)}$ & $\begin{array}{l}\text { 5'-AGTCTCTTCGCCCCAATTTC-3' } \\
\text { 5'-ACTGAAAGCGCACAAGCACT-3' }\end{array}$ \\
\hline$\beta$-actin (AB372563.1) & $\begin{array}{l}\text { 5'-ACGAGAAATCGTGAGGGATG-3' } \\
\text { 5'-ATTCTGCCTTTGCAATCCAC-3' }\end{array}$ \\
\hline
\end{tabular}


To confirm the RT-PCR results, the relative expression levels of 22 genes were also estimated by real-time PCR in two grapevine cultivars. The mRNA accumulation patterns of 22 genes were consistent with the results of RT-PCR (Figs. 2 and 3). Overall, 17 and 16 types of mRNA in 'Kyoho' and 'Campbell Early', respectively, were up-regulated, while five types of mRNA in 'Kyoho' and six in 'Campbell Early' were down-regulated by low temperature treatment. Among the tested genes, the transcript levels of Glu, GST, PGIP, $P R P 2$, and TLP increased greatly in 'Kyoho' grapevines treated with low temperature for 2 or 4 weeks, while the transcript levels of Glu, GST, PGIP, PRP2, and TLP increased greatly in 'Campbell Early' treated with low temperature for 2 or 3 weeks (Fig. 2). However, the total levels of $C B F 1$, $C L P, C I, G P A T, M A P K$, and P5CS gene expression decreased in response to low temperature treatment when compared
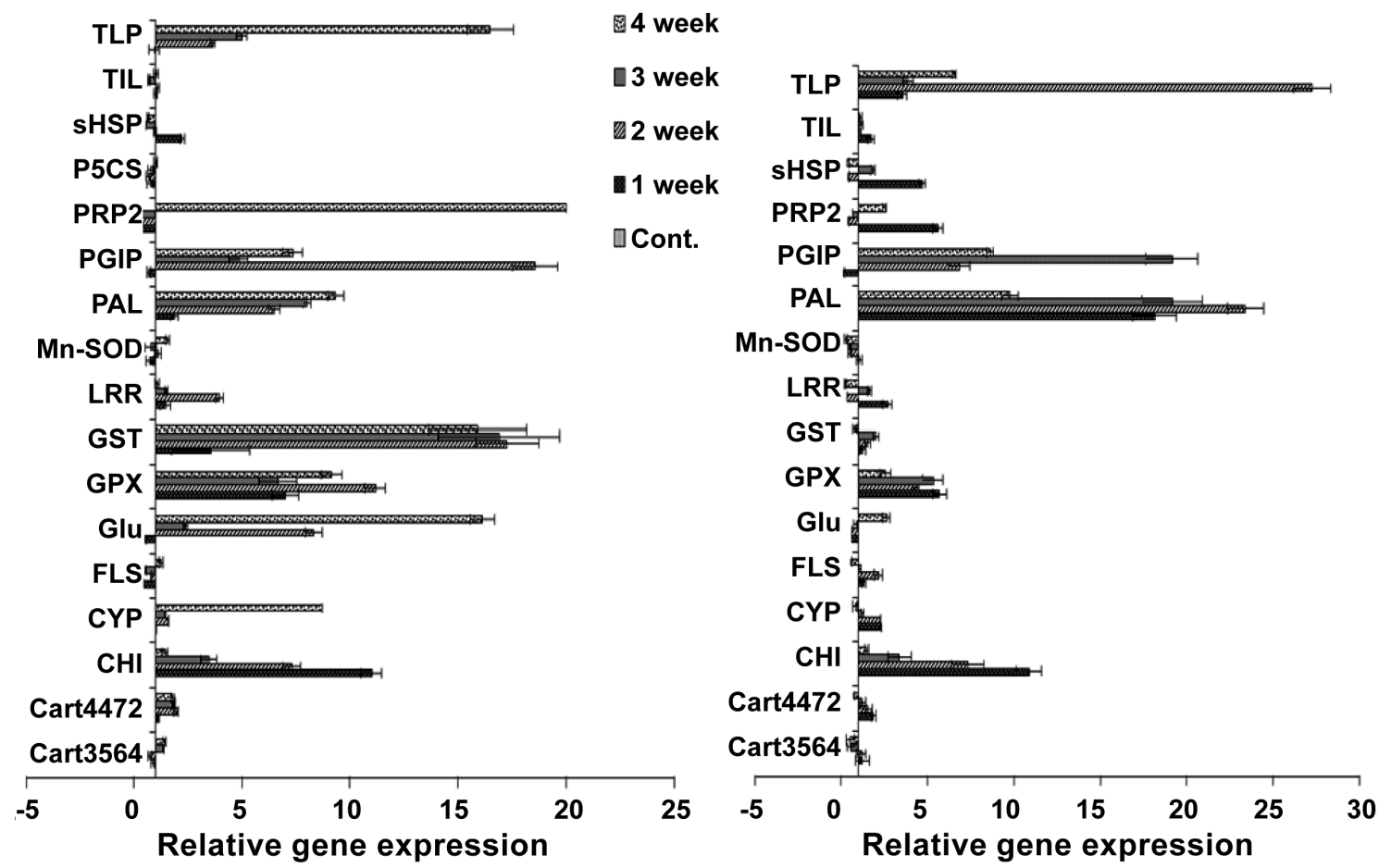

Fig. 2. Quantitative real-time PCR analysis of up-regulated gene expression in 'Kyoho' (left) and 'Campbell Early' (right) in response to cold. Cart3564 and Cart4472, carotene; CHI, chalcone isomerase; CYP, cytochrome P450; FLS, flavonol synthase; Glu, endo- $\beta$ -glucanase precursor; GPX, glutathione peroxidase; GST, glutathione-S-transferase; $L R R$, leucine-rich repeats; $M n$ - $S O D$, manganese superoxide dismutase; $P A L$, phenylalanine ammonia lyase; $P G I P$, polygalacturonase-inhibiting protein; $P R P 2$, proline rich protein 2; P5CS, pyrroline-5-carboxylate synthase; $S H S P$, small heat shock protein; $T I L$, temperature induced lipocalin; $T L P$, thaumatine-like protein. Vertical bars indicate the SEs $(n=3)$.

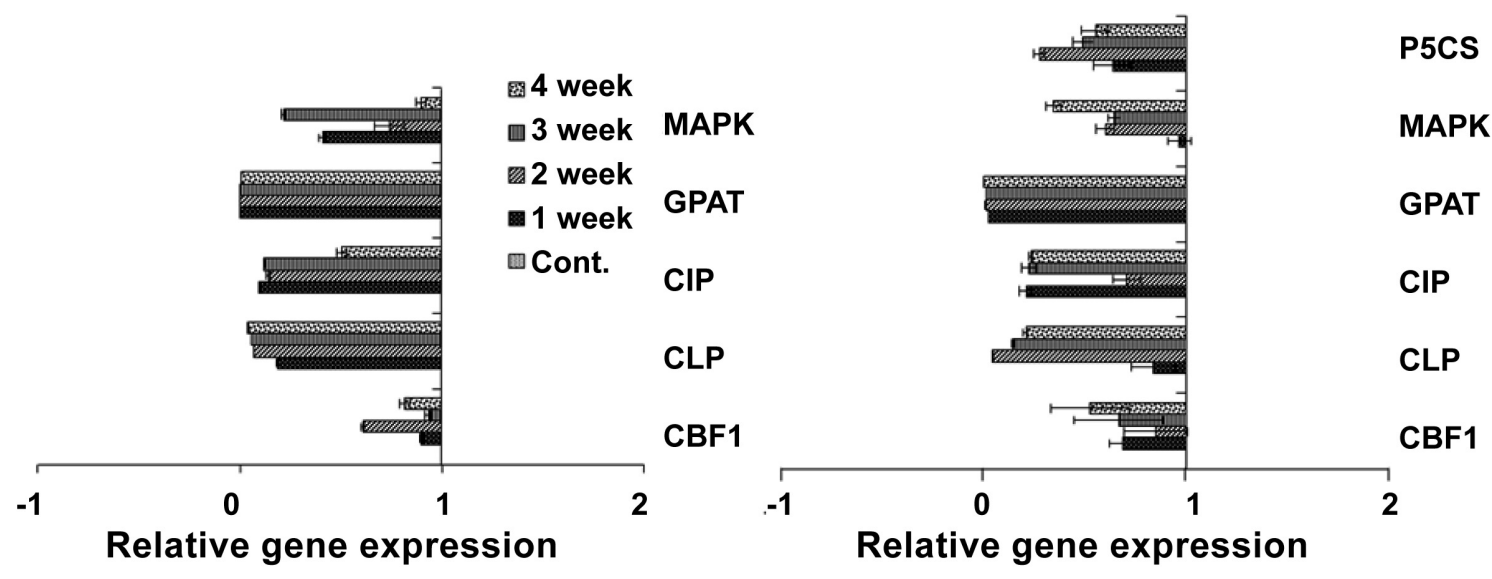

Fig. 3. Quantitative real-time PCR analysis of down-regulated gene expression in 'Kyoho' (Left) and 'Campbell Early' (Right) in response to cold. CBF1, CBF like transcription factor; CLP, chitinase-like protein; CIP, cold induced protein; GPAT, glycerol-3phosphate acyltransferase; MAPK, mitogen-activated protein kinase; P5CS, pyrroline-5-carboxylate synthase. Vertical bars indicate the SEs $(n=3)$. 
with untreated controls in both 'Kyoho' and 'Campbell Early' grapevines (Fig. 3).

The Venn diagram (Fig. 4) shows the distribution of significantly induced and repressed gene expression features during the low temperature treatment period for both grapevines. Among the genes tested in this study, some genes showed up-regulated expression patterns, while others showed down regulated expression patterns by low temperature in grapevines. Among them, P5CS gene showed up-regulation in 'Campbell Early' and down-regulation in 'Kyoho' grapevine. It is worth noting that the expression of the P5CS gene following cold treatment differed between 'Kyoho' (sensitive) and 'Campbell Early' (moderately tolerant) grapevines. The different expressions of this gene likely resulted from the difference in responses to cold and cold-acclimation capabilities. Accordingly, these candidate sequences with different expression to cold could be a valuable tool for development of functional molecular markers to assist in selection during breeding programs.

Low temperatures activated a number of cold-inducible genes such as those that encode active oxygen species (AOS) accumulation or scavenging, cell membrane proteins, molecular
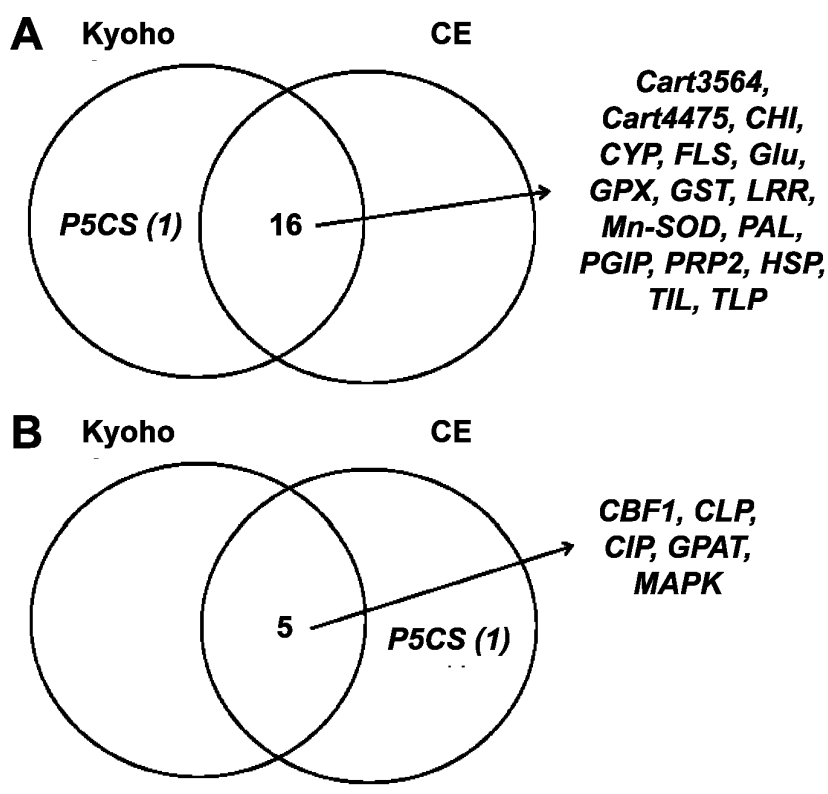

Fig. 4. Venn diagrams of differentially expressed genes in shoots of 'Kyoho' and 'Campbell Early' grapevines in response to cold. A, up-regulated genes; B, down-regulated genes. Cart3564 and Cart4472, carotene; CBF1, CBF like transcription factor; $\mathrm{CHI}$, chalcone isomerase; CLP, chitinase-like protein; CIP, cold induced protein; CYP, cytochrome P450; FLS, flavonol synthase; Glu, endo-ß-glucanase precursor; GPX, glutathione peroxidase; GST, glutathione-S-transferase; GPAT, glycerol-3phosphate acyltransferase; $L R R$, leucine-rich repeats; $M n-S O D$, manganese superoxide dismutase; $M A P K$, mitogen-activated protein kinase; PAL, phenylalanine ammonia lyase; PGIP, polygalacturonase-inhibiting protein; $P R P 2$, proline rich protein 2, P5CS, pyrroline-5-carboxylate synthase; $s H S P$, small heat shock protein; TIL, temperature induced lipocalin; TLP, thaumatinelike protein. chaperones such as HSP, transcription factors (Mahajan and Tuteja, 2005), and PR proteins (Hon et al., 1995). All cold, drought, and salt stresses also stimulate the accumulation of compatible osmolytes and antioxidants (Hasegawa et al., 2000). Huang et al. (2011) reported that accumulation of anthocyanin was enhanced by cold stress, and that transcript levels of $\mathrm{CHI}$ were dependent on interspecific backgrounds being elevated to much higher levels in Poncirus rootstock during cold acclimation. PAL and CHS mRNAs of Arabidopsis were accumulated coordinately in response to low temperatures in a light-dependent manner (Leyva et al., 1995).

AOS are known to be generated in response to chemical and several environmental stresses, including chilling and freezing (Senaratna et al., 1988; Tsang et al., 1991; Wise and Naylor, 1987), drought (Perl-Treves and Galun, 1991; Price and Hendry, 1991), and pathogen attack (Koch and Slusarenko, 1990; Montalbini and Buonaurio, 1986). Mn-SOD transcripts gradually increased in wheat seedlings and remained high for $49 \mathrm{~d}$ of low-temperature stress (Wu et al., 1999). AOS and salicylic acid are known to induce GST levels (Marrs, 1996). Moreover, Jain et al. (2010) found that the transcript levels of Arabidopsis GST genes were induced by desiccation, salt, and cold stress, and that OsGSTU10, which was down-regulated by desiccation stress, was upregulated by cold stress in Arabidopsis.

It has been reported that PGIP transcripts accumulated in apple during cold storage (Yao et al., 1999), as well as in cold-treated Arabidopsis (Ferrari et al., 2003). It was also suggested that low temperatures can increase susceptibility to diseases and that cold induction of defensive proteins might provide protection against pathogen infections. Antimicrobial proteins such as $\beta$-glucanase and chitinase, which are highly homologous with pathogenesis-related (PR) proteins, were found to be accumulated in the leaf apoplast of winter rye after cold exposure (Hon et al., 1995).

Chi et al. (2009) suggested that although plant temperatureinduced lipocalin and $H S P$ were thought to participate in plant responses to heat and cold stress, they are considered to function in different protection systems. The expression of TIL was up-regulated in wheat and Arabidopsis treated with heat shock and cold acclimation (Charron et al., 2002). Additionally, the expression of Arabidopsis TIL1 was significantly increased upon cold acclimation in Arabidopsis leaf (Kawamura and Uemura, 2003).

In this study, 67 plant defense related genes responding to biotic or abiotic stress in the pathway of PR protein, cell modification, AOS accumulation or scavenging, anthocyanin synthesis, and molecular chaperones were selected for screening for differential expression in two grapevines during cold treatment. The expression of various genes associated with 
cold stress was induced or repressed by cold treatment. Differential expression was also screened between 'Kyoho' and 'Campbell Early' grapevines responding to cold stress.

Through comparative analysis of genes induced by cold stress between 'Kyoho' (sensitive) and 'Campbell Early' (moderately tolerant) grapevines, important information useful to understanding the cold response mechanism was obtained. Although this information can be used for the breeding of new grapevine cultivars tolerant to low temperature, a number of valuable genes, which specifically expressed in cold tolerant grapevines, should be selected through further studies such as transcriptome analysis in the future. Sequences of genes with different expression in response to cold could be a valuable tool for development of molecular markers to increase selection efficiency in breeding programs.

\section{Literature Cited}

Chandler, P.M. and M. Robertson. 1994. Gene-expression regulated by abscisic-acid and its relation to stress tolerance. Ann. Rev. Plant Physiol. Plant Mol. Biol. 45:113-141.

Chang, S., J. Puryear, and J. Cairney. 1993. A simple and efficient method for isolating RNA from pine trees. Plant Mol. Biol. 11:113-116.

Charron, J.B.F., G. Breton, M. Badawi, and F. Sarhan. 2002. Molecular and structural analyses of a novel temperature stress-induced lipocalin from wheat and Arabidopsis. FEBS Letters 517:129-132.

Chi, W.T., R.W. Fung, H.C. Liu, C.C. Hsu, and Y.Y. Charng. 2009. Temperature induced lipocalin is required for basal and acquired thermotolerance in Arabidopsis. Plant Cell Environ. 32:917-927.

Dorffling, K., H. Dorffling, G. Lesselich, E. Luck, C. Zimmermann, G. Melz, and H.U. Jurgens. 1997. Heritable improvement of frost tolerance in winter wheat by in vitro-selection of hydroxyproline-resistant proline overproducing mutants. Euphytica 93:1-10.

Feng, D.R., B. Liu, W.Y. Li, Y.M. He, K.B. Qi, H.B. Wang, and J.F. Wang. 2009. Over-expression of a cold-induced plasma membrane protein gene $(M p R C I)$ from plantain enhances low temperature-resistance in transgenic tobacco. Environ. Exp. Bot. 65:395-402.

Ferraria, S., D. Vairo, F.M. Ausubel, F. Cervone, and G. De Lorenzo. 2003. Tandemly duplicated Arabidopsis genes that encode polygalacturonase-inhibiting proteins are regulated coordinately by different signal transduction pathways in response to fungal infection. Plant Cell 15:93-106.

Hasegawa, P.M., R.A. Bressan, J.K. Zhu, and H.J. Bohnert. 2000. Plant cellular and molecular responses to high salinity. Ann. Rev. Plant Mol. Plant Physiol. 51:463-499.

Hon, W.C., M. Griffith, A. Mlynarz, Y.C. Kwok, and D.S. Yang. 1995. Antifreeze proteins in winter rye are similar to pathogenesisrelated proteins. Plant Physiol. 109:879-889.

Huang, Y., Y. Si, and F. Dane. 2011. Impact of grafting on cold responsive gene expression in Satsuma mandarin (Citrus unshiu). Eupytica 177:25-32.

Hughes, M.A. and M.A. Dunn. 1990. The effect of temperature on plant growth and development. Biotechnol. Genet. Eng. Rev. 8:161-187.

Jain, M., C. Ghanashyam, and A. Bhattacharjee. 2010. Comprehensive expression analysis suggests overlapping and specific roles of rice glutathione $S$-transferase genes during development and stress responses. BMC Genomics 11:73-90.

Kang, S.J., K.S. Park, H.K. Yun, Y.S. Lee, and H.R. Kim. 2002. Click! 21st Century's Grape Varieties. National Horticultural Research Institute, RDA, Suwon, Korea.

Kawamura, Y. and M. Uemura. 2003. Mass spectrometric approach for identifying putative plasma membrane proteins of Arabidopsis leaves associated with cold acclimation. Plant J. 36:141-154.

Koch, E. and A.J. Slusarenko. 1990. Arabidopsis is susceptible to infection by a downy mildew fungus. Plant Cell 2:437-445.

Koster, K.L. and D.V. Lynch. 1992. Solute accumulation and compartmentation during the cold-acclimation of Puma rye. Plant Physiol. 98:108-113.

Leyva, A., J.A. Jarillo, J. Salinas, and J.M. Martinez-Zapater. 1995. Low temperature induces the accumulation of phenylalanine ammonia-lyase and chalcone synthase mRNAs of Arabidopsis thaliana in a light-dependent manner. Plant Physiol. 108:39-46.

Lynch, D.V. and P.L. Steponkus. 1987. Plasma-membrane lipid alterations associated with cold-acclimation of winter rye seedlings (Secale cereale L. cv. Puma). Plant Physiol. 83:761-767.

Mahajan, S. and N. Tuteja. 2005. Cold, salinity and drought stresses: An overview. ABB 444:139-158.

Marrs, K.A. 1996. The functions and regulation of glutathione $S$-transferases in plants. Ann. Rev. Plant Physiol. Plant Mol. Biol. 47:127-158.

Montalbini, P. and R. Buonaurio. 1986. Effect of tobacco mosaic virus infection on levels of soluble superoxide dismutase (SOD) in Nicotiana tabacum and Nicotiana glutinosa leaves. Plant Sci. Lett. 47:135-143.

Nomura, M., Y. Muramoto, S. Yasuda, T. Takabe, and S. Kishitani. 1995. The accumulation of glycinebetaine during cold-acclimation in early and late cultivars of barley. Euphytica 83:247-250.

Pennycooke, J.C., S. Cox, and C. Stushnoff. 2005. Relationship of cold acclimation, total phenolic content and antioxidant capacity with chilling tolerance in petunia (Petunia $\times$ hybrida). Environ. Exp. Bot. 53:225-232.

Perl-Treves, R. and E. Galun. 1991. The tomato $\mathrm{Cu}, \mathrm{Zn}$ superoxide dismutase genes are developmentally regulated and respond to light and stress. Plant Mol. Biol. 17:745-760.

Price, A.H. and G.A.F. Hendry. 1991. Iron-catalyzed oxygen radical formation and its possible contribution to drought damage in nine native grasses and three cereals. Plant Cell Environ. 14:477-484.

Senaratna, T., C.E. Mackay, B.D. McKersie, and R.A. Fletcher. 1988. Unicanazole-induced chilling tolerance in tomato and its relationship to antioxidant content. J. Plant Physiol. 133:56-61.

Tillett, R.L., M.D. Wheatley, E.A.R. Tattersall, K.A. Schlauch, G.R. Cramer, and J.C. Cushman. 2012. The Vitis vinifera C-repeat binding protein 4 ( VvCBF4) transcriptional factor enhances freezing tolerance in wine grape. Plant Biotechnol. 
J. 10:105-124.

Tsang, E.W.T., C. Bowler, D. Herouart, W. Van Camp, R. Villarroel, C. Genetello, M. Van Montagu, and D. Inze. 1991. Differential regulation of superoxide dismutases in plants exposed to environmental stress. Plant Cell 3:783-792.

Vivier, M.A. and I.S. Pretorius. 2002. Genetically tailored grapevines for the wine industry. Trends Biotechnol. 20:472-478.

Wise, R.R. and A.W. Naylor. 1987. Chilling-enhanced photooxidation. Evidence for the role of single oxygen and superoxide in the breakdown of pigments and endogenous antioxidants. Plant
Physiol. 83:278-282.

Wu, G., R.W. Wilen, A.J. Robertson, and L.V. Gusta. 1999. Isolation, chromosomal localization, and differential expression of mitochondrial manganese superoxide dismutase and chloroplastic copper/zinc superoxide dismutase genes in wheat. Plant Physiol. 120:513-520.

Yao, C.L., W.S. Conway, R.H. Ren, D. Smith, G.S. Ross, and C.E. Sams. 1999. Gene encoding polygalacturonase inhibitor in apple fruit is developmentally regulated and activated by wounding and fungal infection. Plant Mol. Biol. 39:1231-1241. 